\title{
The Scourge of Religious Conflicts in Tunji Ogundimu's Paradise at Night
}

\author{
Sidi Chabi Moussa, \\ Senior Lecturer of African Literature at the Department of Anglophone \\ Studies, Faculty of Letters, Arts and Human Sciences, \\ University of Parakou (UP), Parakou, Republic of Benin
}

URL:http://dx.doi.org/10.19044/esj.2020.v16n23p80

\begin{abstract}
Religious conflicts have become a serious issue which undermines the African continent and which deserves close attention. So, Marx rightly claims that religion is the opium of the people. This research work aims at examining the scourge of religious conflicts in Tunji Ogundimu's Paradise at Night. It also aims at reflecting on their manifestations and impact on the one hand and on religious and political leaders' limits in their resolution on the other hand. The focus of this research work is limited to a critical appraisal of the novel under study with illustrations. The methodological approaches used in this paper are the phenomenological and descriptive approaches. Based on the example of Nigeria which is the setting of the novel, the findings of the study clearly show that religious conflicts expose innocent people to a lot of harm and that the adherents of the two major religions do not collaborate peacefully. This situation is deplorable insofar as it does not favour development. A country where religious conflicts prevail cannot enhance a lasting development because of their devastating effects. The paper recommends and concludes that Christians and Muslims should promote tolerance, peace and love rather than indulging in violence so that religious conflicts should be eradicated in Nigeria and in Africa at large.
\end{abstract}

Keywords: Religious conflicts, leaders, Christians, Muslims, peace

\section{Introduction}

The Almighty God, who has various names according to the different African ethnic groups and according to the different religions, has created the sky and the earth. The Supreme God has given human beings powers in order to restore peace and unity on earth. Unfortunately, people use these powers to bring harm in society. As statistically shown, religious people kill one another in most countries, especially in African countries. In Africa, many people have 
been separated, kidnapped and even killed simply because they do not share the same religion. So, religious conflicts have become a serious issue which is ruining the African continent. In recent decades, religious conflicts have occurred in African countries, such as Nigeria and Cameroon. For instance, in Nigeria, sixty-two people were killed and thirteen others injured when the Muslims and the Christians attacked one another in April 1991 in Kano State. This research work endeavours to expose the harms that religious conflicts have caused and to clarify the different reasons which are at the origin of these religious conflicts. Tunji Ogundimu's Paradise at Night is used as the basis of the study because he has depicted a society torn by religious conflicts in it. So, religious conflicts have become a serious issue which undermines the African continent and which deserves close attention. The paper is divided into three sections: (1) The Ideology behind the Different Religions and the Causes of Religious Conflicts, (2) Manifestations and Impact of Religious Conflicts, and (3) Religious and Political Leaders' Limits in Religious Conflicts.

\section{The Ideology behind the Different Religions and the Causes of Religious Conflicts}

According to S. M. Nwaomah (2011, p. 96), "Nigeria has three major religions. These are African Religions (Afrel), Christianity and Islam. With a population of about 170 million, Muslims are estimated to be $50 \%$, Christians $40 \%$ and practitioners of African Religions are put at 10\%." Ottuh Peter O. O., Ottuh John A. \& Aitufe V. O. (pp. 49-50) say:

[...] three major religions exist in Nigeria: Islam, Christianity and African Traditional Religion. All religions have a history of radical revivalism. The three religions do not consider each other as friends but rivals. Although the Muslims acknowledge Christ as a prophet, they hold strongly to the teachings of the Qur'an which they believe comes directly from God. They live strictly according to the $\mathrm{Qu}$ 'an and they find it necessary to conquer and bring all the infidels into the true faith, which is Islam. Some Christians on the other hand feel offended by the teachings of Islam and hold strongly to the position that, outside Christ, there is no salvation; all Muslims and traditional religionists will go to hell unless they receive Christ as their personal Lord and Saviour. Related to this is a battle of supremacy between the Muslims and Christians in the political and economical spheres.

The above quotation reveals that among the three major religions existing in Nigeria, Christianity and Islam have conflicting views. There is an ideology behind the different religions, especially Christianity and Islam which are in conflict in Paradise at Night. Although Islam is revealed to 
mankind as a peaceful religion through which the infinite compassion and mercy of God can occur on earth, most leaders of that religion divert it and use it to peddle religious conflicts.

Two main characters, Oluwadara or Dara and Keji, respectively a Christian and a Muslim, have a clear view of the ideology which is the same, not only for the two revealed religions, but also for endogenous ones. Religious conflicts seem to be a serious matter because the adherents of the two religions ignore the ideology behind those religions. Keji, as a Muslim, knows very well that the Noble Qur'an provides an environment where people can fully enjoy the freedom of thought and the freedom of religion and thus live in peace. In the novel, Keji shows that people have the right to live freely whatever their religious beliefs and whoever they may be. Anyone who wants to support or follow any of the religions must be free to do so. The members of religious groups pretend to defend their religions through violence, but Dara confesses that they are making a big mistake because none of the religions teaches violence. He even quotes from the Holy Bible: "Thou shalt not kill" (p. 70). Through that quotation, the novelist refers to the Holy Bible to reveal that it forbids killing, and shows how precious the soul of a human being is. So, the Christian religion strictly forbids its adherents to commit murder. To confirm Dara's stand, Keji declares that Islam too forbids killing and advocates the saving of human lives. He quotes a passage from the Noble Qur'an which says:

" [...]. Kill not anyone. If anyone killed a person it would be as if he killed all mankind, and if anyone saved a life, it would be as if he saved the life of all mankind. The Qur'an even asks: do you believe in a part of the Scripture and reject the rest? Well, our people behave as if they select what to believe in the Scriptures and that is dangerous." (p. 70)

Through the foregoing excerpt, the writer once more proves that the Noble Qur'an too is against murder and thus shows that the soul of any human being is very precious. So, nobody has the right to kill someone else because it is clear that both Christianity and Islam advocate peace and love by strictly forbidding murder. The novelist uses both biblical and Qur'anic references to show that both religions advocate peace in the world through a peaceful collaboration of the two religions. That is the reason why he makes each of those religions call upon their adherents to save the lives of people, because saving a single life is like saving mankind. So, through the above quoted two passages, it is apparent that the ideology behind the two religions is 'the peaceful coexistence of the two religions.' Since this ideology is not respected by most worshippers, Dara asks a series of questions which he, himself, cannot answer: "[...] why should we judge on God's behalf? Why should we judge 
on behalf of the Judge of all judges without recourse to the court of law? Should we ever forget that we came from Him and shall all return to Him?" (p. 71). The contest or duel in the framework of this study is religion or rather Islam and Christianity, the two conflicting religions in the world in general. According to E. Ikenga-Metuh, (1994, pp. 88-89):

The mutual suspicions and fear of domination between the two major religions have been [the] basis for rivalry. This is equally supported by mutual ignorance of the belief and teachings of each one's faith and followed by provocative acts which hurt the religious sensibilities of people of other faiths whether they are intended or inadvertent.

In that quotation, E. Ikenga-Metuh identifies mutual suspicions and fear of domination as the basis of rivalry between the two major religions even though other factors, such as ignorance of the belief and teachings of those religions, foster that rivalry. A religious leader is a person who has followers. As such, his presence is necessary because he is the one who determines his followers' behaviour and actions towards the other religions through his preaching. Unfortunately, religious leaders generally indulge in power abuse and do the opposite of what they are expected to do, thus leading to religious conflicts. Many factors are at the origin of religious conflicts. Among those factors, we can mention the responsibilities of religious leaders in provoking religious conflicts. T. Falola $(2007$, p. 52) corroborates the idea when he argues: "Some religious leaders of each of the religious groups are not doing well for the welfare of the African continent, in fact they destroy it."

The leaders of the different religious groups who are supposed to teach peace and love to their followers teach them nonsense instead. It is the case of Mallam Rimi who is the Muslims' leader in Paradise at Night. Instead of using the words of the Noble Qur'an to preach and advocate peace, he creates his own way of preaching by advocating violence. The following quotation illustrates this fact: "Mallam Rimi said blood is thicker than water. We must fight to protect our rights and our land" (p. 31). That quotation clearly shows how he endeavours to mobilise his followers to create hatred and enmity in their hearts. Through it, the novelist intends to show that the leaders of the Muslim religion are generally at the origin of the religious conflicts that are peddled here and there on the African continent and even beyond. He denounces the use of such words coming from the mouth of a religious leader who is expected to prevent people from pronouncing them.

People consider religious leaders as messengers and respect them very well. However, the words of religious leaders like Mallam Rimi can be sharp like a razor blade, and this can lead to religious conflicts. People respect him in the community depicted in the novel and everybody fears him a lot, 
especially the people of the North (the Hausa) who are mostly Muslims. So, he should normally play role of unifier by telling Muslims to avoid provoking Christians and to consider them as their brothers. Unfortunately, while preaching one day, he further incites his people to kill strangers who are Christians, as it can be seen in the following quotation: "We can shed blood to protect blood, we can shed blood to protect our faith, we can shed blood to protect our land, and we can even shed blood to protect our sweat" (p. 32). Through the quotation, it is clear that Mallam Rimi incites his followers to attack and kill innocent people simply because they are strangers or rather Christians. What is bad in this matter is that what he says is written nowhere in the Holy Qur'an. The writer makes Mallam Rimi say this to show that most religious leaders do not know all the contours of the Holy Books they are supposed to preach, and hence incite their followers to violence.

Imitating their leaders, some followers sometimes make people believe that they master what is written in the Holy Books. It is the case of the character of Hudu who blindly thinks that Mallam Rimi knows everything. The following quotation is a proof of that fact: "Mallam Rimi has got sense, real sense. He knows the Qur'an and he has read books. He is current. He understands these things and he explains them well" (p. 32). Through what Hudu has said, it is apparent that he, himself, knows nothing about the Holy Qur'an. The novelist uses this to show how obstinate and blind some followers are. Hudu blindly follows his master without knowing or acknowledging the wrong he is doing around him. By doing so, Hudu seems to forget that someone who is trusted without analysing his actions can cause a deep blindness and ignorance. To crown his blindness and ignorance, he is ready to follow Mallam Rimi wherever he goes and acts according to the latter's will. The writer thus shows how religious leaders' can badly influence their followers' lives to the extent of misleading them and making them have a bad behaviour in society. This is a kind of slavery. Such an utter 'slavery' leads followers like Hudu to support their leaders who breed and nurture religious conflicts here and there in the name of Islam. The leaders of each religion are responsible for those conflicts. However, the followers who do not avoid supporting and encouraging them are to be blamed.

A fervent worshipper should love the people around him whether they belong to his religion or not. As such, he should be a model in the community in which he lives as far as the promotion of peace and love is concerned. So, one wonders what kind of worshipper and religious leader Mallam Rimi is. Without doubt, if he were a good leader, he would avoid showing hatred instead of love towards Christians in his community. How can a person who calls himself a religious leader ask his followers to kill people just because they do not belong to their religion? It is evident that it is not fair at all. It is true that religious leaders are responsible for such a situation, but the followers 
who fail to face facts and to avoid indulging in it are also responsible for it. If any follower wants to follow the right way, he does not need to listen to a preacher who will ruin his life for nothing. Alli, a character in the novel, exemplifies this fact. As a matter of fact, he tries to persuade his friend, Hudu, who discriminates against the Christians whom he considers as strangers, to abdicate, but in vain. Hudu persists in his obstinacy as shown in the quotation below:

"Complete nonsense. If somebody lives here for decades, does that make him one of us? I think you are foolish! Strangers are not meant to lord it over the natives. Go and listen to Mallam Rimi. He said only foolish people will allow strangers to direct their affairs. All of us cannot be foolish. Understand? That is why we have to fight." (p. 31)

Through the above quotation, the novelist tries to show the extent to which discrimination can occur in a country because of religious difference. What Hudu says is purely nonsensical as he considers his countrymen as strangers within their country. He urges Alli to go and listen to Mallam Rimi who considers those who fail to abide by his preaching as foolish people. The writer wisely makes Alli, a fervent Muslim, refuse to listen Mallam Rimi and to follow him blindly. The following quotation is a proof:

Alli said he was going nowhere and would not listen to anybody, including Mallam Rimi. He preferred listening to his parents. "Wherever you lived and prosper is your town. That is what my parents say and I will go by that. I don't want to be brainwashed." (p. 33)

In the aforementioned excerpt, Alli clearly reveals that that he is accountable to nobody but his parents. Through that quotation, the novelist shows that there are Muslims who avoid following their leaders blindly. In the same vein, through Alli's refusal to abide by Hudu's dictate to follow Mallam Rimi, the writer intends to show that all the Muslims do not discriminate against 'strangers' or Christians. Like Alli, there are followers who really master the Noble Qur'an and apply its peaceful verses without distorting them. This is a very commendable behaviour. Among the Pastors and Imams, there are those who really preach the words of God. Pastor Eze and Dara's father exemplify this as they categorically refuse to resist to those provokers who are responsible for religious conflicts in the novel. There are some people who engage in some domains that they know nothing about. It is the case of Mallam Rimi who apparently knows nothing about Islam or the Qur'an or fails to implement the right verses of the Holy Koran. But still, he embraces the religion, becomes a religious leader, and teaches people what has nothing to 
do with Islam. Many religious leaders fail to preach by using the right approach. On the contrary, they preach by using the wrong approach. The following quotation illustrates that fact:

[...]. They might have failed because the approach was wrong; because they did not pray or plan enough. In any case, there are no reasons why citizens of the same nation should be fighting each other. And there is no reason why they should be killing their brothers and sisters. No reasons whatsoever. (pp. 68-69)

In the foregoing quotation, Dara unveils some religious leaders' lack of competence. Through that quotation, the novelist clearly shows the extent to which the fact of preaching by using the wrong approach leads religious leaders to incite their followers to commit atrocities through murder. There is no reason why they should incite the citizens of the same nation to fight one another. Because of their divergent religious beliefs, brothers attack their siblings or friends and cause the separation of families. According to $\mathrm{S}$. Awoniyi (2013, p. 125), "The two received religions predominant in Nigeria with their longstanding rival ideologies have a history of ethno-political antagonisms." In the quotation, it is clear that Islam and Christianity are the two received religions that $\mathrm{S}$. Awoniyi is referring to.

\section{Manifestations and Impact of Religious Conflicts}

Many different things happen before the advent of religious conflicts. Before the conflicts begin, people observe prejudice and hatred from both sides. Prejudice is a pervasive problem in society which can negatively impact lives, sometimes in deadly ways. It can have a strong influence on how people behave and interact with others, particularly with those who are different from them. It refers to the belief, thoughts, feelings, and attitude that someone holds about a group. It is not based on experience; instead, it is a prejudgement originating from outside actual experience. Mallam Rimi exemplifies this fact in Paradise at Night insofar as he holds a prejudicial attitude toward people who do not belong to his religion. People like him paint every individual who holds particular characteristics or beliefs with a very broad brush and fail to really look at each person as a unique individual. Prejudice can distort the way people should normally see other people because it is a complex phenomenon which leads to war, enslavement, abuse, suffering and murder. Common features of prejudice include negative feelings and the tendency to discriminate against the members of a group. When religious groups are not free to practise their faith, frustration may turn into aggression, finally leading to armed conflicts. This excerpt from the novel illustrates it: 
"You've killed my father ...," sister Joke started.

"Kai!" one of them muttered and punched her face to shut her up. Another kicked her tummy, she fell down and the men closed up on her. She screamed. (p. 4)

That excerpt clearly shows that in the novel, the Muslims have enough prejudicial attitudes towards the Christians, without any sound reasons. They do so simply because they consider them as strangers or disturbers. Although the Christians neither react nor resist, the Muslims keep on having prejudicial attitudes toward them, thus forgetting or failing to acknowledge that prejudicial attitudes lead to conflicts. So, prejudice is a baseless and usually negative attitude towards the members of a group. As far as Mallam Rimi is concerned, he considers the Christians as troublemakers. He even confesses that they are not following or serving the right religion. The prejudice that he has upon them causes him to lead his followers astray and to create religious conflicts. Through this, the novelist shows that Muslims are generally at the origin of prejudice which inevitably leads to religious conflicts.

Hatred is also considered as one of the signs of religious conflicts. It is a human emotion, a deep and emotional extreme dislike that can be directed against individuals, or ideas. It can invoke feelings of animosity, anger, or resentment which can be directed against certain individuals, groups, concepts, or ideas. Hatred is capable of preventing people from seeing the good side of things, thus impeding dialogue. For example, Mallam Rimi indulges in hatred because of mere hearsay. As a matter of fact, when a Muslim neighbour has overheard Dara's father's comments while preaching, he goes to see Mallam Rimi, his Imam, and makes an exaggerated account of it to him so much so that he gets angry and furious. While making an unfounded report, the clumsy Muslim encourages religious conflicts. He has misinterpreted what Dara's father has said. As a guest speaker at a revival organised by the church, Dara's father tries to bring unity between Muslims and Christians in his sermon. The narrator tells us what he has said in his speech in these terms:

In his speech, he had said that our leaders were not doing enough to champion the unity of the country. He equally stated that most of our political leaders were opportunistic and could not be entirely trusted. "It does not even matter if the Governor of a state is a Muslim or a Christian; a leader should live above board. Also, religious leaders should always promote peace and not violence. They should slam all forms of malpractice." (p. 52) 
The above-mentioned quotation reveals that Dara's father has not mentioned the name of any Muslim, religious leader or Governor in his speech. However, "Pastor Eze explained that a Muslim neighbour of a local Imam had overheard his comments. On getting home, he made an exaggerated account of it to his Imam who grew furious" (p. 53). It is clear that the Muslim neighbour has distorted what Dara's father has really said. Of course, this causes Mallam Rimi to plot Dara's father's death without seeking to find out what the latter has really said. The misinterpretation of what Dara's father has said has brought about his death. In his fury, Mallam Rimi goes too far as it can be seen in the following quotation: "Why should a kafir refer to a Chief Imam in a Christian sermon? Why should he insult the State Governor? That is an anti-Islamic posture. The man must pay for his indiscretion" (p. 53). As a result, a gang led by Mallam Rimi, himself, goes to Dara's father's house and kills him with a knife. The excerpt below is an illustration:

The gang leader cackled, "Kafir". He was huge man with a big tummy. From a distance, his beard looked like a hand fan; it was long, bushy and partly grey in the middle. He tugged at it and turned to one of his companions standing close to Father. He raised his right hand to his neck, palm down and moved it left and right in quick succession. He nodded his head and barked, "Keshe shi". Two of the attackers went for my father's legs. Father fell flat on his face and struggled in vain against the two men. A third aggressor grabbled his hands and pinned him down. He continued to struggle but his captors were too strong for him. A fourth man brandished a long knife, bowed and went for father's throat. I trembled with fear and closed my eyes. My father howled loudly with pain and then there was silence. (p. 3)

Through the aforementioned excerpt, we can see that Muslims are so cruel. The gang decides to kill Dara's father simply because he is not a Muslim, which is not fair. The novelist thus unveils and deplores the fact that some Muslims kill innocent people in the name of Allah to satisfy their selfish interests. In the same vein, he shows how gossip can bring about turmoil or rather religious conflicts. The Holy Qur'an says nowhere that Muslims should kill. Through the murder of Dara's father, the writer intends to show the cruelty of the so-called Muslims in the novel. This entails the following question: Why should people kill other people in the name of a religion which advocates peace and love? Instead of getting patient, Mallam Rimi, the 'fake' local Imam, gets irritated and decides to retaliate. That is how hatred can lead to religious conflicts. Hatred can motivate violent crimes and damaging behaviour, such as the intolerance of Mallam Rimi who categorically refuses 
to accept the Christian religion. He has become a religious extremist. I. T. Sampson (2012, p. 118) comments on religious extremists in these terms:

Religious extremists are therefore religious fundamentalists, who take religious conservatism and intolerance to an unreasonable extent, by manifesting violence against those who hold contrary religious views. Religious extremists take the position that if others do not follow their ways, they will be damned $[\ldots]$. They abhor the preaching of other faiths and resort to violence to stop it. They insist that their religious doctrines must be universally entrenched by brute force, while the political, social and economic systems must conform to their religious tenets. Religious extremism does not admit of any compromise with social change, particularly that which contradicts religious orthodoxy.

In the above quotation, I. T. Sampson unveils what religious extremists think about the other religions. They think that all those who do not share their religious views are against them. They want everybody to follow their faith, which is impossible. They consider their preaching as the only true one. So, I. T. Sampson's view corroborates the idea that Mallam Rimi is a religious extremist. People like him seem to forget that they live in a given community and that they have the obligation to maintain peace in it at all costs. In addition, they fail to acknowledge that once they commit themselves to living together, that choice is an implicit form of social contract. If that social contract is observed well, understanding, cooperation, tolerance and workable agreements are bound to occur. However, if it is not observed well, it leads to a kind of injury which brings about frustration. Hence aggrieved victims may seek to even the score at the next opportunity. If they take revenge, the vicious circle of frustration, wounds and vengeance stands complete and peace is gone. In most African societies, when it becomes too painful for someone to swing his arm, he lifts them up onto his head and cries for help. It is the case of the main character in the novel, Oluwadara or Dara, who definitely becomes an orphan because of religious conflicts. He has lost his father and his younger sister, Joke, an innocent young girl, who has nothing to do with the conflict. After killing Dara's father like a goat, the gangsters have killed Joke as it can be seen through this quotation:

[...] when I opened my eyes, I saw that my father's throat had been slashed. His blood was gushing out; it was like a ram being slaughtered on Ileya day. 
From behind the door where I stood, I was overcome with anger and grief. I struggled not to scream as I remained glued to the wall like a statue. Tears flowed from my eyes.

"You've killed my father ...," sister Joke started. "Kai" one of them muttered and punched her face to shut her up. Another kicked her tummy, she fell down and the men closed up on her. She screamed. I closed my eyes filled with terror. (pp. 3-4)

The foregoing quotation shows how terrible Mallam Rimi and his gang are. If not, how can a person kill such a little girl without any pity or fear of mind? Why kill people simply because they are Christians? Through the innocent girl's murder, the novelist intends to denounce the killing of innocent people by some Muslims. As the saying goes: 'When two elephants fight, the grass suffers'. That African saying justifies the fact that when religious conflicts occur between two religious groups, innocent people are those who suffer a lot. For example, Dara suddenly becomes an orphan and a homeless boy at a tender age. After the rioters have killed his father and his sister, they have burnt their house, and this has put Dara into a serious issue. Since most of his extended family members live at Kenta in Abeokuta in the South, he has nowhere to live after the destruction of their house.

Religious intolerance can be observed at different levels, firstly among the adherents of the same religion (intra-religious intolerance), and secondly among the adherents of two or more religions (inter-religious intolerance). "It encompasses bigotry, which is the obstinate and intolerant devotion to one's opinions and prejudices, especially the exhibition of intolerance and animosity toward persons of differing beliefs" (R. M. Baird and S. E. Rosenbaum, 1999, cited by I. T. Sampson, 2012, p. 114). According to R. I. Gofwen (2004, p. 50, cited by I. T. Sampson, 2012, p. 114), "Religious intolerance has been identified as the major source of religious conflict/violence in all societies existing as long as the history of mankind, and permeating all forms of human civilisations, with attendant destructive tendencies." In Paradise at Night, inter-religious intolerance occurs, and the Christians are its victims. The excerpt below illustrates that fact:

"Aren't we all Rabbenians?" [...].

"We are from different regions. And we always feel very strongly about our regions. If outsiders want to direct our affairs we shall stop them; we shall force them back to their states. And, if they persist, we shall fight or kill them." (p. 32)

The above excerpt clearly shows that the Muslims, represented by their leader, Mallam Rimi, discriminate against the Christians whom they consider as 'outsiders' in their own country simply because they are not Muslims. 
Discrimination and intolerance affect the society in general, and the young people who experience it in particular. Discrimination and intolerance can be seen through the attitude of the Muslims of Borri, led by Mallam Rimi. Through the occurrence of these vices, the writer deplores the fact that they facilitate the killing of innocent people without any good reason through religious conflicts. There are always problems or violence between the different religions all over the world, which causes insecurity. In Paradise at Night, religious conflicts have brought insecurity in a fictitious town called Borri. It is a town in which the majority of the population are Muslims and at the same time Hausa, which refers to Northern Nigeria. Because of the prevalent insecurity, fear has filled the minds of most people who resort to confinement and hide in their houses. So, there is an ambient class struggle between Muslims and Christians. Marx's famous assertion that 'religion is the opium of the people' is justified here insofar as the adherents behave exactly like people who have taken opium which is a drug. In other words, they behave like opium addicts because of their extreme fanatical behaviour which leads them to commit atrocities.

Sometimes the circumstances of life can change the plan of each human being. In Paradise at Night, the main character, Dara, is living in good conditions with his parents. Then, the group of fake Muslims and their leader, Mallam Rimi, have come to modify everything in his life. Despite the fact that Dara is a sixteen-year-old boy, he sleeps outside. He is thus bound to become a street child, and his living conditions become too hard. Through Dara's plight, the novelist denounces the consequences that religious conflicts may entail. O. K. Sulaiman (2016, p. 92) is therefore right when he deplores the extent of religious conflicts in Africa in these terms: "Religious conflicts remain an issue which is ruining the African continent... Parents have lost their children and children have also lost their parents. No country will develop with this kind of situation." The quotation reveals the impact of religious conflicts on human lives. O. K. Sulaiman thus refers to the rising incidence of religious violence in Africa, especially in Nigeria. In Paradise at Night, those who carry loads are called alábàárù (a mere porter). Dara is bound to become one of them to survive, since he has lost his parents and his only sister. Later, he leaves that job and works in a garage where he serves as an agbèrò (someone who collect money from passengers). He does all these petty jobs in order to survive.

Some people change their identity in order to avoid problems with other religious groups and thus escape from murder. For instance, Dara's Christian name is David, but wherever people ask him his name, he always gives Oluwadara or Dara which literally means 'The Lord is good' in the Yoruba language. He uses this name because the people of Borri do not like Christian names in their majority. So, the best thing to do is to hide his name 
from them in order to avoid trouble. The novelist uses this as subterfuge to enable Christians to hide their true names, and to some extent their real identity, and adopt Muslim or traditional names so as to escape from murder during religious conflicts. Anyway, almost all the Christian names have their equivalent in Islam, since the Holy Books (the Qur'an and the Bible) have more or less the same contents in fact; only the languages in which they are written differ.

Religious conflicts are no more a problem of one country, but it now concerns the whole African continent. The gang attacks where there are a lot of people: sometimes at church, funerals, or meetings. N. Wakam, a journalist at Africa 24, says:

The attack on a Protestant church in Silgadji, Northern Burkina Faso, during which four (4) worshippers and the pastor were killed, is causing concern in the country. The attack on the church last weekend is the first against a church since 2015, the year of the first Jihadist attacks. They attacked the church because it's one of their targets. Terrorist groups attack a number of targets and the church is one of the symbolic targets that they attack. And they want to show [that] there is an inter-religious conflict through the church, and it is the local populations that are the most at risk.

That quotation shows how innocent people have been killed in the church while praying. The journalist thus deplores the inter-religious conflict which has led to the attack of the church by terrorists. Religious conflicts also have devastating effects on African educational standards. Instances are the closure of schools, the destruction of school facilities, and the abduction and the rape of school children. In Paradise at Night, Dara's schooling has stopped after the attack of his family. He has left school for a while since he has lost his home and parents. Apart from that, he has decided to leave the crises area (Borri) in order to survive. When religious conflicts occur, the terrorists go to some schools in order to recruit young children and sometimes to abduct the teachers and the kids. J. C. Aguwa (1997, p. 349) corroborates the idea as follows:

Schools are also many times used as recruitment ground for terrorist groups because schools provide easy access to children. In Somalia, terrorists have used schools to recruit children into their ranks. In 2016 (Nigeria), thousands of school children were abducted with their teachers from their schools. During the religious attacks, the school children were abducted for religion education sessions, and while most returned after a few days, many were abducted with the aim of having them participate in 
the conflicts. Between January and August 2015 alone, more than 11,800 students were abducted from rural schools by terrorist for indoctrination or forced recruitment. And most of the members of this group (terrorists) are youth.

In the foregoing quotation, J. C. Aguwa shows how religious conflicts affect education in many ways. As a matter of fact, religious conflicts cause a great havoc to the educational system of the country where they occur. For instance, they may cause the destruction of schools, as well as educational infrastructures. Religious conflicts may also affect the youth, since many young people and even children are involved in them and thus become delinquents or criminals. Those conflicts therefore entail juvenile delinquency. In Paradise at Night, apart from Mallam Rimi who is the leader of the rioters, the rest of the members are youths. They do not respect anyone except their leader, Mallam Rimi.

During religious conflicts, children become impolite, and most of them always copy what their parents do. So, religious conflicts affect many children. In Paradise at Night, the characters of Hudu, Shittu, and Banda exemplify this fact. Those young people have been disrespectful towards an old woman at school just because they are not from the same religious group. The woman cannot react or say anything because she is afraid of being killed, since the children's parents follow Mallam Rimi. Through the three children's behaviour, the writer intends to show how innocent children are trained to become child soldiers in Africa. Without doubt, such children end up becoming ruthless killers in the long run and cause religious conflicts which have a great impact on the economy of the African continent because they pervade all the sectors of the economy. S. M. Nwaomah (2011, p. 101) corroborates the idea when he writes:

The resultant effects of religious conflicts in Nigeria are enormous. It pervades all the sectors of the economy. Generally, conflicts breed insecurity, discrimination, mutual distrust and slow economic and educational development. This is the case in Nigeria where in addition to the gratuitous killings and maiming of thousands of persons, properties worth billions of naira have been destroyed. Certainly, these huge losses have deprived the nation of needed manpower and services for the growth of its wobbling economy.

The aforementioned excerpt unveils the effects of religious conflicts on Nigeria where the novel under study is set. Apart from the gratuitous killings and maiming of a great number of people, the two conflicting parties have destroyed considerable quantities of properties. This situation has a great 
impact on the economy of the country because the very people who are supposed to serve as manpower and boost the economy are among the victims. S. M. Nwaomah (2011, pp. 101-102) further states:

Religious conflicts in Nigeria have also left its effect on investment options in the crises ridden areas. The political instability, arising from the insecurity and uncertainty that pervades the region, does not inspire the confidence of foreign investors and thereby deprives the nation of the economic gains. In some instances, the enterprising Southerners who had established thriving businesses in the troubled areas in the North have relocated to other and safer places. Further, religious conflicts in Nigeria have left in its trail a broken society: communities that hitherto co-existed peacefully now treat each other with mistrust and latent or open aggression. Consequently, settlement patterns begin to follow the boundaries of religion in these areas so that adherents can be swiftly mobilized in the event of future riots. The disrupted social harmony is sometimes felt in places far from the crisis scene and thus account for the reprisal riots in other parts of Nigeria.

From the above-mentioned quotation, it appears that foreign investors will not accept to invest funds in a country which is divided by religious crises. There is fear at two levels: the basic aim of foreign investment is to make profit, which is not possible in an environment of crises. Moreover, the resources already invested will definitely go down the drains. As a result, those who are supposed to invest in order to ameliorate the economy of the country categorically refuse to do so. Generally, conflicts breed insecurity, discrimination, mutual destruction and slow down the economic development of a country. The case of Nigeria where the novel under study is set is very telling. In the novel, Pastor Eze tries to explain to his followers how the rioters have come to his house and later to the church to scatter everything. They have also burnt all the properties that are in the church and the remaining fortune left for the church. This excerpt is an illustration:

The premises were practically empty. Only the carcass of the pastor's burnt Honda car was visible in the left-hand corner. It had been raised in an earlier crisis. [...]

Parstor Eze stood up and prayed. Then he recounted how our church had lost seven members as well as properties worth millions of Naira in the latest crisis. "We are all affected by this crisis, individually and collectively; directly or indirectly," he said. (p. 50) 
That excerpt shows how religious conflicts can definitely ruin people's lives and fortune. It reveals that the rioters have not only killed seven members of the church, but they have also burnt the pastor's car and have destroyed properties worth millions of Naira. Another major consequence of religious conflicts on the economic development of Africa is the bad reputation of African communities where they prevail. Many countries have started seeing Nigeria as a terrorist country; and this affects not only the businessmen who travel to that country, but also the economic development of the country. For instance, in Paradise at Night, Dara's uncle, Alhaji, who is a businessman refuses to go to Borri because of religious conflicts. Some people even run away and leave their precious activities in order to save their souls. However, no country can develop without integration. When religious conflicts separate people in a country and they fail to unite, the country can never progress.

\section{Religious and Political Leaders' Limits in Religious Conflicts}

When religious conflicts occur in a country, it is the duty of the government to maintain peace and unity. The African civilians of the concerned countries always criticise and blame the government for not being able to solve the problem and for not doing enough to bring peace and unity in the different countries. For instance, in Paradise at Night, Dara's father tries to denounce the irresponsibility of African governments as far as religious conflicts are concerned. This quotation is an illustration: "Our leaders were not doing enough to champion the unity of the country; most of our political leaders were opportunistic and could not be entirely trusted" (p. 52). Through this quotation, the novelist unveils the incapacity of African governments to solve crises, especially religious conflicts. He makes Dara's father demonstrate how the members of the government have failed to find solutions to the religious conflicts in the fictitious country depicted in the novel. Instead of putting in their efforts in order to maintain peace and unity in the country, they only stay in their offices without doing anything. The novel reveals that the government of Borri State does not even react to the situation. As a result, the rioters are free in their bad practice.

In the novel, Dara's father and Pastor Eze have played a capital role. They do not abuse of their power despite the fact that they are the leaders of the Christians. In order to maintain peace, Dara's father never retaliates to the rioters. In addition, if Pastor Eze had behaved like Mallam Rimi, there would have been a lot of deaths. When Mallam Rimi and his gang have attacked the church, Pastor Eze, as a good religious leader, refuses to retaliate. Moreover, when Pastor Eze has lost most of his properties during the attack, he refuses to retaliate. "His wife and children had been dispatched to their home in the South East. His misfortune was not as serious as father's but he had learnt his lesson" (p. 50). He could have gone to the church to mobilise his followers in 
order to take revenge, but he has not done so. He reacts as a good leader who should give good examples to his followers and to his community at large, instead causing violence. He shows how a good leader should react for the welfare of the population. So, Pastor Eze and Dara's father may be qualified as heroes. The writer uses them as model religious leaders whose footsteps should be followed by Muslim religious leaders in general.

Dara too has played an important role although he has lost his family and many things during the religious conflicts. This is justified by the fact that he is determined to follow his father's footsteps by leading people in a commendable way despite what he has undergone. He believes that those who kill one another ignore what they are doing and that they do not receive good sermons from their respective leaders. For this reason, he decides to become a man of God as it can be seen in the following quotation: "I want to teach the people to live in peace and eschew violence" (p. 68). According to Dara, there are two main ways of preventing religious conflicts: by preaching the truth to the followers and by being a responsible religious leader. Through that quotation, the novelist unveils the great responsibility of a religious leader who should be a model for his followers and for society at large. He makes Dara show that he will teach people the good path to follow and do what is essential to stop and even to prevent violence between the Muslims and the Christians. Dara's refusal to abdicate shows that he plays the role of a religious leader despite his tender age. When Keji advises him to avoid going back to his house since he was "lucky to come out alive from the lion's den" (p. 69), he boldly replies: "Maybe, God has spared my life so He could use me to tell our people to shun violence because the Holy Bible says: Thou shalt not kill" (p. 70). Dara's behaviour, despite the fact that he is in danger, is a very commendable act which deserves being followed by all leaders - government or religious leaders - who have to adopt such strategies in order to preserve peace in their countries. In some cases, religious conflicts are beyond control because the government fails to take the problem seriously. Boko Haram, has now become a serious problem for the Nigerian government. The aim of this group (Boko Haram) is to impose sharia on the entire nation. As M. H. Kukah (2010, p. 14) puts it, "[...] the Boko Haram opposes Western education and insists on upholding and imposing shariah legal system." Despite the military power of that nation, the government has not succeeded in stopping these religious conflicts or in arresting the leader of the group. According to D. R. Smock (2006, p. 17):

Tens of thousands of people have perished in Nigeria over the last five years due to violence between Christians and Muslims. The worst of the violence has occurred in Plateau State. The most recent Christian-Muslim conflict in Plateau State occurred in Yelwa-Nshar, in the Shendam local government area, where 
nearly 1,000 were killed in May 2004. When I visited Nigeria in November 2004, I witnessed several mass graves for Muslims and one for Christians, with each grave containing 100 bodies. The killings in Yelwa-Nshar provoked reprisals in both Kano State and Southeastern State. To subdue the unrest in Plateau State, 25,000 soldiers and security personnel were deployed. The administrator of Plateau State convened a peace conference that resulted in recommendations for resolving the conflicts, but the Muslim community rejected them.

The foregoing quotation reveals that religious conflicts seem to become lasting, since D. R. Smock has mentioned five years which are too much. Christian-Muslim conflicts generally take place in the Plateau State where the Muslims have rejected the recommendations resulting from a peace conference. Most religious and political leaders fail in maintaining peace because they ignore their responsibilities towards the worshippers and the population. So, they have a great responsibility in religious conflicts. In Paradise at Night, the impartial attitude of political and religious leaders is clearly mentioned through what the General Overseer - Dara's father - says: "It does not even matter if the Governor of a state is a Muslim or a Christian's leader should live above board. Also, religious leaders should always promote peace and not violence. They should slam all forms of malpractice" (p. 52). Through the quotation, the writer uses Dara's father as his mouthpiece to show the role of religious and political leaders in peace building. According to him, they should promote peace rather than peddling violence. Talking about the role of political leaders in maintaining peace, it is important to notify that a political leader should be impartial. That is to say, a political leader should not favour, in any case, the different religions. Moreover, he should endeavour to fight intolerance, starting from the family nucleus.

Africa is still affected by religious conflicts that undermine the efforts to bring about sustainable socio-economic development that is required for the continent to effectively compete in the international arena. Peace and security are therefore a prerequisite for sustainable development on the continent. The prevention of religious violence, the promotion of dialogue and the peaceful resolution of these conflicts are therefore vital. Peace building plays an important role in this regard. So, D. R. Smock (2006, pp. 110-111) is right when he says:

Religion is a significant factor in the identity of one or both paths to the conflict; religious leaders on both sides of the dispute can be mobilised to facilitate peace; leaders have the great responsibilities for the welfare of the worshippers. They are obliged to promote peace among the population. By way of 
example, African peacemaker Hizki Assefa emphasises the commendable role of religious leaders as an asset in peace making. Such religious leaders are particularly effective in working together for peace. When they are from different faiths, explore and practice common values, such as justice and compassion, in public life, religious leaders can be an inspiration to others.

Through the aforementioned excerpt, D. R. Smock unveils the responsibilities of religious leaders for peace building in Africa. Through African leaders' responsibility in religious conflicts, the author has mentioned the effort made by some African societies. In fact, no community can develop without peace. The peace guarantors who include the governments, civil society groups, traditional and religious institutions, local councils of churches or mosques, the private sector, the business community, and the media need to work towards reducing religious conflicts in Africa. Referring to religious leaders in particular, O. Ogunnubi and D. Ettang (2018, p. 40) write:

The leaders of each religion should permit people to worship their God freely, and the two religions give nearly the same message and believe also in the same Almighty God, whom the Muslin called Allah. We recommend that the leaders should put hands together in order to find a category solution to this issue of religious conflict which is running down the economic and politic of African countries.

In the foregoing quotation, O. Ogunnubi and D. Ettang insist on religious leaders' responsibility in the prevention and resolution of religious conflicts, since their followers consider them as wise people and often imitate them. As such, they are the key actors in the resolution of religious conflicts. However, there is hope because according to D. R. Smock (2006, p. 17):

Although Muslim-Christian relations in Nigeria are usually tense and too frequently violent, a local evangelical pastor and an imam have been forging peace in Yelwa-Nshar and other parts of Nigeria. The United States Institute of Peace (USIP) offers advice and financial support, but theirs is truly an indigenous effort.

In the above quotation, D. R. Smock reveals that a local evangelic pastor and an imam endeavour to forge peace in Nigeria, which is a very commendable act. The two religious leaders have shown that violence is useless in their country. They have greatly contributed to peace building in the 
country. Referring to the two religious leaders, D. R. Smock (2006, p. 17) further writes:

In 1995, they recognized that their two faiths both contain warrants for peace. They established the Inter Faith Mediation Centre, and committed themselves to work collaboratively to promote interfaith reconciliation. In 1999, they coauthored a book titled, The Pastor and the Imam: Responding to Conflict (Lagos: Ibrash Publications, 1999), which describes their experiences and sets out the biblical and Koranic mandates for peace. Since then, they have helped bring religious peace to the troubled city of Kaduna. With USIP support, they have trained many religious youth leaders to be peacemakers, as described in the next section.

The above-mentioned quotation clearly shows that the Pastor and the Imam have enormously contributed to peacebuilding, not only by creating an Inter Faith Mediation Centre, but also by coauthoring a book which advocates reconciliation and unity of action even through its title. As S. M. Nwaomah (2011, pp. 102-103) suggests:

The Christian and Muslim leaders in Nigeria must continue to reach out and sustain the dialogue processes, spearhead interreligious education and seek every opportunity to educate its followers and others on the ills of violence and the Christian alternatives to the culture of retaliation. It also behooves the Christian and Muslim communities to reject the manipulative acts of some political leaders, who constantly seek ways to flame the nation with violence under the guise of religious patriotism, for their selfish political interests. It is only sustained efforts in these directions that will build the Nigerian nation despite the different religious ideologies espoused by its people.

Christian and Muslim leaders should endeavour to impress on their followers the teaching on the solidarity of humankind.

The foregoing excerpt shows that peacebuilding mainly lies in the hands of Christian and Muslim leaders who have a great role to play to put an end to the Christian-Muslim conflicts in Nigeria, and in Africa at large.

\section{Conclusion}

This research work has dealt with three sections. The first section has revealed the ideology behind the different religions on the one hand, and the causes of religious conflicts on the other hand. The second section has 
examined how religious conflicts are manifested in the novel and their impact. The third section has shown that both religious and political leaders have limits in the resolution of religious conflicts. The novelist has used various literary techniques to convey his message. He has reached his goal by impacting his readership. He has succeeded in drawing the readers' attention to the dangers inherent in religious conflicts and to the necessity of finding lasting solutions to them. Needless to say, religious conflicts as they are revealed in Paradise at Night remain a great issue which the African continent faces today and which needs urgent and lasting solutions.

\section{References:}

1. AGUWA Jude C., 1997, "Religious Conflicts in Africa: Impact on Nation Building", in Dialectical Anthropology, Vol. 22, No. 3/4, pp. 335-351.

2. AWONIYI Sunday, 2013, "A Discourse on Religious Conflict and Tolerance in Multi-Faith Nigeria", in European Scientific Journal, Vol. 9, No. 20, pp. 124-143.

3. IKENGA-METUH Emefie, 1994, "Two Decades of Religious Conflict in Nigeria: A Recipe for Peace", in Bulletin of Ecumenical Theology, Vol. 6, No. 1, pp. 69-93.

4. KUKAH, Matthew H., 2010, "Boko Haram: Some Reflections of Causes and Effects", in S. O. Anyanwu and I. Nwanaji (Eds.), Boko Haram Religious Conflicts and Dialogue Initiatives in Nigeria, Owerri: Edu-edy, pp.1-28.

5. NWAOMAH Sampson M., 2011, "Religious Crises in Nigeria: Manifestations, Effects and the Way Forward", in Journal of Sociology, Psychology and Anthropology in Practice, Vol. 3, No. 2, pp. 94-104.

6. OGUNDIMU Tunji, 2012, Paradise at Night, Campus Publications Ltd, $92 \mathrm{p}$.

7. OGUNNUBI Olusola and ETTANG Dorcas, 2018, "Interrogating the Role of Religious Leaders and Institutions in Conflict Management in Plateau State, Nigeria", in Dele Babalola and Hakeem Onapajo (Eds.), Nigeria, a Country under Siege: Issues of Conflict and its Management, UK: Cambridge Scholars Publishing, pp. 180-201.

8. OTTUH Peter O. O., OTTUH John A. \& AITUFE V. O., 2014, "Christian - Muslim Relations in Nigeria: The Problems and Prospects", in AFRREV IJAH : An International Journal of Arts and Humanities, Vol. 3 (2), S/No 10, pp. 46-62.

9. SAMPSON Isaac Terwase, 2012, "Religious Violence in Nigeria: Causal Diagnoses and Strategic Recommendations to the State and 
Religious Communities", in African Journal on Conflict Resolution, Vol. 12, No. 1, pp. 103-133.

10. SMOCK David R., 2006, "Mediating Between Christians and Muslims in Plateau State, Nigeria", in SMOCK David R. (Ed.), Religious Contributions to Peacemaking: When Religion Brings Peace, Not War, Washington, DC: United States Institute of Peace, pp. 17-20.

11. SULAIMAN Olawale Kamal-Deen, 2016, "Religious Violence in Contemporary Nigeria: Implications and Options for Peace and Stability Order", in Journal for the Study of Religion, Vol. 29, No. 1, pp. 85-103.

12. WAKAM Nathalie, 2019, "Burkina Faso: Security Expert Warns of Inter-Religious Conflicts", in Africa 24 (April 30th, 2019). 